\title{
Evaluation of Performance of New Wheat Cultivar under Different Row Spacing
}

\author{
Dhiman Mukherjee* \\ Department of Agronomy, Bidhan Chandra Krishi Viswavidyalaya, \\ Kalyani-741 235, Nadia, West Bengal, India \\ *Corresponding author
}

\begin{abstract}
A B S T R A C T
A field experiment was conducted at District Seed Farm (AB Block), Kalyani under Bidhan Chandra Krishi Viswavidyalaya during winter season of 2014-16in upland situation to study the effect of date of sowing on the growth and yield of wheat genotypes with an objective to optimize row spacing for yield maximization in wheat genotypes. The experiment was carried out in a split plot design with three wheat genotypes (HD 2977,

Keywords

Cultivar,

Spacing,

Wheat,

Yield.

Article Info

Accepted:

29 May 2017

Available Online:

10 June 2017 DBW 103, K 0307, HD 2733 and DBW 39) and three row arrangements (15, 18 and 21 $\mathrm{cm}$ ) and experiment was replicated thrice. Amongst various tested cultivars, highest LAI at 50 and 65 DAS was registered with the HD 2967 and K 0307, respectively. Both are at par to each other and significantly superior to other set of treatments. Statistically more number of tillers $/ \mathrm{m}^{2}$ was observed with the HD 2967 and showed parity with the HD 2733. Number of tillers $/ \mathrm{m}^{2}$ maximum observed with $18 \mathrm{~cm}$ and significantly better to rest of the assorted units. Further, days to $50 \%$ heading least observed with the $21 \mathrm{~cm}$ row spacing, and significantly superior to other treatments. Moreover, days to physiological maturity took least time with the $15 \mathrm{~cm}$ spacing and statistically better to other set of treatments. Grains per ear head was highest registered with the DBW 39 and showed parity with the K0307, and significantly better to other treatments. Test weight failed to produce any significant response. Highest grain yield was registered with the HD 2967 (3.79 t/ha), and was at par with the DBW 39 (3.41 t/ha) and K0307 (3.21 t/ha), and statistically better to rest of the treatments combination. More straw yield was observed with HD 2967 (5.94 t/ha) and was at par with DBW 39 (5.41 t/ha). With various subplot treatments, maximum grain and straw yield was observed with the $18 \mathrm{~cm}(3.53$ and $6.03 \mathrm{t} / \mathrm{ha})$, and showed parity with $15 \mathrm{~cm}$ row spacing (3.21 and $5.87 \mathrm{t} / \mathrm{ha})$. Highest $\mathrm{B}$ : C ratio recorded with the HD 2967 (1.70) with row spacing of $18 \mathrm{~cm}(1.64)$.
\end{abstract}

\section{Introduction}

Agriculture is the forte of India and West Bengal is among the top ten wheat producing states. West Bengal has set an ambitious target to be self-sufficient in wheat production within few years. West Bengal is not a traditional wheat growing state in India. However, at present, wheat has become a staple food crop next to rice and its consumption is gradually increasing because of change in food habit and economic prosperity. In spite of a wide range of adoptability, little attention has been paid towards wheat production and maximization of yield potential of this crop in West Bengal and its share to national production is quite less. Scientist has ample scope to enhance its 
productivity and production levels with improved agronomic manipulations. Since wheat is a major cereal crop and population is gradually increasing, increase in its production and acreage should be given top priority in order to achieve food and nutritional security in the state. Wheat is generally planted by broadcast method by most of the farmers in this state. Now-a-days due to infestation of weeds, it has become necessary to sow the good genotype in lines with a suitable row spacing, which may help in cultural operations, herbicides application, inter-cropping and increasing or decreasing seed rate without any adverse effect on the final grain yield (Mukherjee, 2016). Appropriate cultivars with proper row spacing is important for maximizing light interception, penetration, distribution in crop canopy and average light utilization efficiency of the leaves in the canopy, and thus affect yield of a crop. Wider spacing between rows or pairs of rows, not only allow more light to reach the lower leaves at the time of grain formation but also allows easy inter-culture for weed control and inter-cropping (Ayaz et al., 1999). Similarly Nazir et al., (1987) and Hussainet al. (2003) led to the conclusion that wheat grain yield was not reduced to a significant extent by increasing the row spacing and suggested that wider planting geometry technology can be adapted without any risk of reduction in yield, may facilitate inter-tillage devices for effective weed control and inter-cropping in wheat. Knowledge of yield components responses to manipulations of management inputs is basic for the establishment of consistent and profitable intensive management system for wheat. The grain yield is a function of interaction between genetic and environmental factors like soil type, sowing time and method, seed rate, fertilizers and time of irrigation. Among these factors proper genotype with appropriate row spacing plays a vital role in getting higher grain yield. Keeping this in view, the present investigation has been undertaken during the winter season of 201416 to evaluate the effect rowspacing on growth and productivity of wheat genotypes under new alluvial zone of West Bengal.

\section{Materials and Methods}

The field experiment was conducted at District Seed Farm (AB Block), Kalyani under Bidhan Chandra KrishiViswavidyalaya during winter season of 2014-16in upland situation. The farm is situated at approximately $22^{\circ} 56^{\prime} \mathrm{N}$ latitude and $88^{\circ} 32^{\prime} \mathrm{E}$ longitude with an average altitude of $9.75 \mathrm{~m}$ above mean sea level (MSL). The soil of the experimental field was loamy in texture and almost neutral in reaction having $\mathrm{pH}$ 7.2, organic carbon 0.4 [3\%, available nitrogen $241 \mathrm{~kg}$, available phosphorus 23.2 and available potassium $244 \mathrm{~kg} / \mathrm{ha}$. The experiment was carried out in a split plot design with five wheat genotypes (DBW 107, HD 2967, K 0307, HD 2733 and DBW 39) and three row arrangements (15, 18 and 22 $\mathrm{cm}$ ) and experiment was replicated thrice. Wheat genotypes were assigned to main plot and spacings were assigned to sub plots. The length of each plot was $8 \mathrm{~m}$ (nine rows of wheat). The sowing of crop was done on $21^{\text {st }}$ November, 2014 and 23rd November 2015 using recommended seed rate of $100 \mathrm{~kg} / \mathrm{ha}$ using $150 \mathrm{~kg} \mathrm{~N}, 60 \mathrm{~kg} \mathrm{P_{2 }} \mathrm{O}$ and $40 \mathrm{~kg} \mathrm{~K}_{2} \mathrm{O} / \mathrm{ha}$. The crop was harvested as per maturity of the crops. The data pertaining to growth and yield attributes and yield were analyzed statistically as per methods suggested by Gomez and Gomez (1995).

\section{Results and Discussion}

\section{Growth parameters}

Amongst various tested cultivars, highest LAI at 50 and 65 DAS was registered with the HD 2967 and K 0307, respectively. Both are at 
par to each other and significantly superior to other set of treatments. Statistically more number of tillers/m2was observed with the HD 2967 and showed parity with the HD 2733. The results indicated that inherent tillering potential per unit area of HD 2967 was relatively higher than that of other tested genotypes. Days to $50 \%$ heading was least registered with the $\mathrm{K} 0307$ and was at par with the HD 2967 (Table 1). Further, days to physiological maturity was least registered with the DBW 107 and showed parity with the K0307. Statistically analyzed data on days to physiological maturity revealed that among all the genotypes, DBW 107 took minimum period for attaining physiological maturity followed by K0307. These treatments were at par to each other. Maximum duration for physiological maturity was observed with the HD 2733. The variation of genotypes were statistically significant with regard to the days required for attaining physiological maturity with various subplots treatments, LAI failed to produce any significant reply at 50 DAS, however highest LAI during this period was recorded with $15 \mathrm{~cm}$ row spacing. Further observation revealed that, at 65 DAS more LAI registered with the $18 \mathrm{~cm}$ row spacing and showed parity with the $15 \mathrm{~cm}$. Lowest LAI was recorded with wider spacing. Angiras and Sharma (1996) also reported that the closer spacing help to increased LAI significantly over wider spacing, because of its influence in reducing the weed biomass and weed growth rate and increasing CGR of the crop. No. of tillers/m 2 maximum observed with $18 \mathrm{~cm}$ and significantly better to rest of the assorted units. Further, days to $50 \%$ heading least observed with the $21 \mathrm{~cm}$ row spacing, and significantly superior to other treatments. Moreover, days to physiological maturity took least time with the $15 \mathrm{~cm}$ spacing and statistically better to other set of treatments.

Table.1 Effect of various treatments on growth character of wheat

\begin{tabular}{|c|c|c|c|c|c|}
\hline \multirow[t]{2}{*}{ Treatment } & \multicolumn{2}{|c|}{ LAI } & \multirow[t]{2}{*}{ No. of tillers $/ \mathrm{m}^{2}$} & \multirow{2}{*}{$\begin{array}{c}\text { Days to } 50 \% \\
\text { heading }\end{array}$} & \multirow{2}{*}{$\begin{array}{c}\text { Days to } \\
\text { physiological } \\
\text { maturity }\end{array}$} \\
\hline & $50 \mathrm{DAS}$ & 65 DAS & & & \\
\hline \multicolumn{6}{|c|}{ Cultivars } \\
\hline DBW 107 & 2.04 & 2.78 & 298.0 & 69.3 & 110.0 \\
\hline DBW 39 & 2.11 & 3.03 & 305.6 & 72.2 & 115.8 \\
\hline K 0307 & 2.89 & 3.42 & 319.6 & 68.1 & 112.0 \\
\hline HD 2733 & 2.51 & 3.11 & 405.3 & 71.1 & 116.9 \\
\hline HD 2967 & 3.12 & 3.35 & 422.0 & 68.9 & 115.0 \\
\hline S.Em \pm & 0.05 & 0.06 & 20.11 & 0.21 & 0.65 \\
\hline C.D. $(\mathrm{P}=0.05)$ & 0.17 & 0.21 & 61.2 & 0.65 & 2.05 \\
\hline \multicolumn{6}{|c|}{ Row spacing (cm) } \\
\hline 15.0 & 2.68 & 3.36 & 401.8 & 71.8 & 111.7 \\
\hline 18.0 & 2.61 & 3.46 & 433.6 & 70.9 & 114.4 \\
\hline 21.0 & 2.71 & 2.97 & 311.0 & 68.7 & 113.9 \\
\hline S.Em \pm & 0.03 & 0.08 & 20.05 & 0.13 & 0.11 \\
\hline C.D. $(\mathrm{P}=0.05)$ & NS & 0.25 & 68.11 & 0.51 & 0.33 \\
\hline
\end{tabular}


Table.2 Effect of various treatments on yield attributing and yield of wheat

\begin{tabular}{|c|c|c|c|c|c|c|c|}
\hline Treatment & Earhead $/ \mathbf{m}^{2}$ & $\begin{array}{c}\text { Grains/ } \\
\text { Earhead }\end{array}$ & $\begin{array}{c}\text { Test } \\
\text { Weight } \\
\text { (g) }\end{array}$ & $\begin{array}{l}\text { Grain } \\
\text { yield } \\
(\mathbf{t} / \mathrm{ha})\end{array}$ & $\begin{array}{c}\text { Straw } \\
\text { yield } \\
\text { (t/ha) }\end{array}$ & $\begin{array}{c}\text { Harvest } \\
\text { Index } \\
(\%) \\
\end{array}$ & $\begin{array}{l}\text { B:C } \\
\text { ratio }\end{array}$ \\
\hline \multicolumn{8}{|c|}{ Cultivars } \\
\hline DBW 107 & 234.1 & 37.8 & 39.3 & 2.36 & 4.01 & 38.66 & 1.02 \\
\hline DBW 39 & 278.3 & 42.3 & 41.0 & 3.41 & 5.41 & 37.48 & 1.67 \\
\hline К 0307 & 289.6 & 41.2 & 40.2 & 3.21 & 4.98 & 39.19 & 1.71 \\
\hline HD 2733 & 264.1 & 38.3 & 41.8 & 2.98 & 5.01 & 37.29 & 1.44 \\
\hline HD 2967 & 298.6 & 40.8 & 42.9 & 3.79 & 5.94 & 38.95 & 1.70 \\
\hline S.Em \pm & 5.11 & 0.48 & 0.91 & 0.23 & 0.19 & 1.41 & \\
\hline $\begin{array}{l}\text { C.D. } \\
(P=0.05)\end{array}$ & 16.02 & 1.26 & NS & 0.71 & 0.60 & NS & \\
\hline \multicolumn{8}{|c|}{ Row spacing $(\mathrm{cm})$} \\
\hline 15.0 & 301.3 & 41.0 & 42.1 & 3.21 & 5.87 & 35.35 & 1.59 \\
\hline 18.0 & 319.2 & 42.3 & 43.8 & 3.53 & 6.03 & 36.92 & 1.64 \\
\hline 21.0 & 271.5 & 40.9 & 42.2 & 2.77 & 4.91 & 36.06 & 1.45 \\
\hline S.Em \pm & 2.77 & 0.61 & 0.71 & 0.11 & 0.22 & 1.33 & \\
\hline $\begin{array}{l}\text { C.D. } \\
(\mathrm{P}=0.05)\end{array}$ & 13.16 & NS & NS & 0.32 & 0.68 & NS & \\
\hline
\end{tabular}

\section{Yield parameters}

Yield attributing characters play significant role with various treatments, and highest earhead/m2 was observed with the HD 2967 and showed parity with the K0307 and statistically superior to other set of treatments (Table 2). Grains per earhead was highest registered with the DBW 39 and showed parity with the K0307, and significantly better to other treatments. Test weight failed to produce any significant response with any other genotype, however maximum test weight recorded with the HD 2967. With various sub plot treatment highest earhead $/ \mathrm{m} 2$ was observed with the row spacing of $18 \mathrm{~cm}$ and was at par with the $15 \mathrm{~cm}$ row spacing, and statistically better to other set of treatments (Table 2). However, grains /earhead failed to produce any significant response with various treatments, highest number of grains /earhead was registered with the $18 \mathrm{~cm}$ row spacing. Wider distance between plants within rows in narrow spacing might have ensured the plant little competition for light, water, and nutrients from other plant and thus influenced the crop in narrow spacing to higher yield attributing values. HD 2967 recorded higher 1000 grains weight followed by HD 2733, however, the difference amongst the genotypes was notsignificant. Higher 1000 grains weight in HD 2977 was attributed to their comparatively well-developed bold grains compared to others (Table 2). No significant difference among the treatments (row spacing) had been found, but a higher test weight was evident in case of $18 \mathrm{~cm}$ row spacing. It was also observed that there was progressive decrease in 1000 grains weight as the distance between rows was increased from $18.0 \mathrm{~cm}$ to $21 \mathrm{~cm}$. These findings are in accordance with Thakur et al., (2000). 


\section{Yield}

Highest grain yield was registered with the HD 2967 (3.79 t/ha), and was at par with the DBW 39 (3.41 t/ha) and K0307 (3.21 t/ha), and statistically better to rest of the treatments combination. Higher values in ear head $/ \mathrm{m} 2$ and number of grain /ear head might have resulted in higher grain yield in HD 2967 and K0307. The lowest yield was recorded from DBW 107 and HD 2733 (Table 2). Grain and straw yield varied significantly as a result of different row spacing. More straw yield was observed with HD 2967 (5.94 t/ha) and was at par with DBW 39 (5.41 t/ha). With various subplot treatments, maximum grain and straw yield was observed with the $18 \mathrm{~cm}(3.53$ and $6.03 \mathrm{t} / \mathrm{ha}$ ), and showed parity with $15 \mathrm{~cm}$ row spacing (3.21 and $5.87 \mathrm{t} / \mathrm{ha}$ ). Closer spacing produced more straw yield as compared to the other treatments. This result is in conformity with Bakht et al., (2007) stated that straw yield varied significantly due to planting densities. Among the row spacing the highest straw yield was obtained from the plots of 18 $\mathrm{cm}$ row spacing followed by $15 \mathrm{~cm}$ row spacing. More number of tillers $/ \mathrm{m} 2$ and higher LAI might be responsible for influencing higher straw yield in $18.0 \mathrm{~cm}$ spacing. Lower grain and straw yield registered with wider spacing. This collaborates with the findings of Mali and Choudhary (2013) and Mukherjee (2014). Hence, considering the results, it may be concluded that all the five tested wheat genotypes gave high yields when grown in narrow row spacing of $18 \mathrm{~cm}$ instead of 21 $\mathrm{cm}$ spacing under new alluvial zone of West Bengal. In this study, $18.0 \mathrm{~cm}$ row spacing produced higher yield attributes along with higher yield indicating better resource utilization in narrow rows than wider rows. Increased light capture by a canopy has also been reported in wheat with narrow row spacing. Harvest index was highest observed with the HD 2967, moreover it failed to produce any significant response with various cultivar under main plot treatments. The results are in conformity with the findings of Bakht et al., (2007) who noted that the effect of row spacing and interactions with varieties were not statistically significant in case of harvest index. Harvest index was not significantly influenced by row spacing. However it was noted higher (36.92\%) in 18 $\mathrm{cm}$ spacing and the least was noted in $15.0 \mathrm{~cm}$ spacing (Table 2). Highest B:C ratio recorded with the HD 2967 (1.70) with row spacing of $18 \mathrm{~cm}$ (1.64).

\section{References}

Angiras, N.N. and Sharma, V. 1996. Influence of row orientation, and row spacing and weed control methods on physiological performance of irrigated wheat (Triticum aestivum). Indian journal of Agronomy, 41(1): 41-47.

Ayaz, S., Shah, P., Sharif, H.M. and Ali, I.1999. Yield, yield components and other important agronomic traits of wheat as affected by seed rate and planting geometry. Sarhad Journal of Agriculture, 15: 255-262.

Bakht, J., Qamer, Z., Shafi, M., akber, Habib, R., Masoodur, A. and Khan, M. 2007. Response of different wheat varieties to various row spacing, Sarhad Journal of Agriculture. 23 (4):47-52.

Gomez, K.A. and Gomez, A.A. 1995. Statistical Procedures for Agricultural Research.John Willey and Sons, New York, pp.97-107.

Hussain, I, Muhammad, A. K and Khalil, A. 2003.Effect of row spacing on the grain yield and the yield component of wheat (Triticum aestivum L.). Journal of Agronomy, 2: 153-159.

Mali, H. and Choudhury, J. 2013. Performance of bread wheat (Triticum aestivum L.) varieties under different 
row spacing, Journal of Wheat Research. 4(2): 55-57.

Mukherjee, D. 2014. Consequences of planting date and seed rate on yield and economics of wheat (Triticum aestivum) under rainfed terraced situation. Indian Journal of Crop Ecology, 2 (2): 29-34.

Mukherjee, D. 2016. Influence of fertility levels on the performance of wheat cultivars under new alluvial zone of West Bengal. Journal of Agroecology and Natural Resource Management, 3(3): 206-208.
Nazir, S.M., Hussain, A., Ali, G and Shah, R.H. 1987. Conventional versus new geometry of planting wheat. Pakistan Journal of Agriculture Research, 8: 125129.

Thakur, Singh, Dhaliwal, G.S. and Singh, T. 2000. Performance of wheat varieties under late sowing conditions in southwestern region of Punjab. Journal of Research, PAU. 37 (3-4): 181-183.

\section{How to cite this article:}

Dhiman Mukherjee. 2017. Evaluation of performance of new wheat cultivar under different row spacing. Int.J.Curr.Microbiol.App.Sci. 6(6): 3186-3191.

doi: https://doi.org/10.20546/ijcmas.2017.606.375 